\title{
Malaysia Ten Years After The Asian Financial Crisis
}

\author{
Lee Poh Ping and Tham Siew Yean
}

\section{Introduction}

When the Asian financial crisis hit Malaysia, the impact was traumatic. There was economic and political turmoil. The stock market, the currency and the property market nearly collapsed. That in turn affected the overall economy. UMNO, the dominant political party in the ruling alliance, experienced political turbulence when its charismatic deputy president, Anwar Ibrahim, was expelled from the party when he disagreed with the then president, Mahathir Mohamad, over, among other things, Mahathir's rejection of loans from the International Monetary Fund(IMF). Yet, Malaysia was not that badly affected as compared to some of its neighbours. It did not experience the extent of the socio-political distress as occurred in Indonesia where the rioting that broke out ultimately led to the overthrow of Suharto. Nor was its economic sovereignty that deeply compromised as happened in Indonesia and Thailand when both countries were forced to accept the conditions imposed by the IMF for the acceptance of their loans. What then had been the impact of the crisis on Malaysia? This year, the tenth year of the crisis, offers us an opportune time to consider this question.

This paper will consider the impact on the following. It will first consider the impact on the overall Malaysian economy. Beginning with the nature of the crisis, this section continues with the government response and with the reasons for the recovery of the economy. The second section analyses the impact on Malaysian Chinese business, especially on those firms which survived, those which collapsed and those which successfully restructured. Focusing on this business gives us an idea as to how this very important part of Malaysian business fared under the crisis. The impact on the political system will form the third section. As the effect of the crisis on the constitutional structure is not evident and is minimal on the role of the bureaucracy, this section deals primarily with the impact on the dominant political party, UMNO, and the possibility of reform. Finally, the impact on the Look East Policy(LEP) will be examined. It will consider how the crisis eroded the justification that a particular form of government and business relationship, as idealized in the Japanese model, can produce impressive economic growth and social stability.

\section{1)The overall impact on the Malaysian economy and the government response}

The crisis in Malaysia first began with developments in the Malaysian currency. As a result of the precipitate withdrawal of money from Malaysia, the value of the Malaysian Ringgit began to swing wildly. From a value of 2.52 to the US dollar in June, 1997, it went down to 3.2 to the US dollar in September, 1997, just three months after the crisis struck. It reached a new low of 4.5 Ringgit to the US dollar in January,1998!(Tourres.2003,78,193) This severely exacerbated the decline of the Malaysian stock market, which already had been on a downward trend before the crisis, as the depreciation of the Ringgit led to panic selling by foreign investors. From a value of 1271 points in February 1997, the Kuala Lumpur Composite Index (KLCI ) fell to 897.25 on August 12, 1997 immediately after the crisis struck, and 
reached a historic low of 262 a year after on 1 September, 1998. The huge drop of the Ringgit and the stock market had a devastating impact on highly geared enterprises, particularly those companies that had taken loans from abroad. The sharp decline of the stock market and the specter of many of these highly geared companies unable even to service interest on loans then created pressure on bank liquidity. This liquidity crunch resulted in a general loss of confidence in the Malaysian economy, and eventually precipitated a massive contraction in the Malaysian economy from 7.3\% growth in 1997 to a low of $-7.4 \%$ in 1998 (see Table 1). Per capita income fell from RM9.1 billion to RM8.2 billion in the same period while foreign direct investment (FDI) shrank from RM14.5 billion to RM8.5 billion due to the negative impact of the crisis on corporate profits, retained earnings and investor confidence (Table 1).

Confronted with these developments, the Malaysian government did not, like many of the other affected countries, resort to the IMF. It decided to form a National Economic Action Council (NEAC), a high powered group chaired by the Prime Minister, and a consultative body to the Cabinet, to help stabilise the economy. The action taken by the NEAC on one level consisted of attempts to reduce the pressure on the Ringgit. These involved the imposition of selective capital controls and the pegging of the Ringgit to the US dollar at 3.8 on September 1, 1998, roughly a year after the crisis struck. On another level, the NEAC tried to stabilise the banking system and to restructure affected business. To the former end, the NEAC established two institutions , Danaharta(the National Asset Management company) to relieve the banking system of its non-performing loans(NPLs) and assets and Danamodal( a National Capital Fund) to help the banks recapitalise. As to the latter end, the Corporate Restructuring Committee(CDRC) was also established.(Chin 2004,206) It would seem that the government has achieved some success as seen in the recovery of the Malaysian economy from 1999 onwards (Table 1). The GDP which experienced negative growth of 7.4 percent in 1998 went pack to positive growth of 6.1 percent in 1999 . The GDP continued to grow subsequently.

Table 1. Summary of Macro-economic Statistics for Malaysia, 1995-2005.

\begin{tabular}{rrrrrrrrr}
\hline \multicolumn{2}{c}{$\begin{array}{c}\text { GDP } \\
\text { (RM million) } \\
\mathbf{1 0 0 = 1 9 8 7}\end{array}$} & $\begin{array}{c}\text { GDP } \\
\text { Growth \% }\end{array}$ & $\begin{array}{c}\text { Population } \\
\text { ('000) }\end{array}$ & $\begin{array}{c}\text { GDPpc } \\
\text { (RM) }\end{array}$ & $\begin{array}{c}\text { Exports } \\
\text { (RM mil) }\end{array}$ & $\begin{array}{l}\text { Imports } \\
\text { (RM mil) }\end{array}$ & $\begin{array}{c}\text { TB } \\
\text { (RM mil) (RM mil) }\end{array}$ & $\begin{array}{c}\text { FDI } \\
\text { (RM }\end{array}$ \\
\hline 1995 & 166,625 & & 20,689 & $8,053.80$ & 179,491 & 179,394 & 97 & 10,464 \\
1996 & 183,292 & 10.00 & 21,169 & $8,658.51$ & 193,363 & 183,275 & 10,088 & 12,777 \\
1997 & 196,714 & 7.32 & 21,666 & $9,079.39$ & 217,713 & 207,439 & 10,274 & 14,450 \\
1998 & 182,237 & -7.36 & 22,180 & $8,216.28$ & 281,669 & 212,453 & 69,216 & 8,490 \\
1999 & 193,422 & 6.14 & 22,712 & $8,516.29$ & 319,568 & 233,519 & 86,049 & 9,397 \\
2000 & 210,557 & 8.86 & 23,275 & $9,046.49$ & 374,033 & 294,889 & 79,144 & 6,694 \\
2001 & 211,227 & 0.32 & 24,013 & $8,796.36$ & 334,326 & 264,472 & 69,854 & 1,091 \\
2002 & 220,422 & 4.35 & 24,527 & $8,986.91$ & 358,504 & 286,387 & 72,117 & 4,935 \\
2003 & 232,359 & 5.42 & 25,048 & $9,276.55$ & 397,969 & 300,207 & 97,762 & 4,194 \\
2004 & 248,954 & 7.14 & 25,581 & $9,731.99$ & 481,240 & 376,766 & 104,474 & 9,739 \\
2005 & 262,029 & 5.25 & 26,127 & $10,029.05$ & 533,380 & 409,312 & 124,068 & -
\end{tabular}

Notes: GDP: Gross Domestic Product; GDPpc: GDP per capita; TB: Trade Balance; FDI: Foreign Direct Investment

Source: Malaysia Economic Statistics-Time Series, Department of Statistics, Malaysia. 


\section{Evaluation}

What helped stabilize the economy? Some argue that the capital controls played a large part as they helped staunch the outflow of capital, and moreover were imposed selectively so as not to discourage foreign investors.(Tourres.2003,188) Investors were free to repatriate profits earned on documented foreign direct investment(FDI) and there were no restrictions imposed on foreign currency transactions for current account purposes. And despite the fact that these controls were imposed sometime after the crisis, they nevertheless still enabled the government to lower domestic interest rates and to pursue expansionary macroeconomic policies.(Athukorala 2002,22) These expansionary policies, in turn, contributed towards economic recovery by expanding public consumption and stimulating the partial recovery of domestic consumption in 1999. The fixed exchange rate also contributed to export recovery as it prevented premature exchange rate appreciation as part of improved market sentiments about the recovery prospects. Others believe otherwise as the controls coming more than a year after the crisis struck amounted to shutting the doors after the horses had bolted. (Jomo 2004,178 ) As noted in the WTO's summary observations in its 2001 Trade Policy Review of Malaysia(2001,vii) at the time the controls were put in place, markets in Malaysia and elsewhere in Southeast Asia appeared to have been stabilized. Whatever the arguments for and against, the controls did not have the kind of dire negative consequences on Malaysia that detractors predicted. In a sense the controls were benign.

There is the question of the efficacy of the restructuring. Many of the Malaysian companies, especially the larger Bumiputra companies, were successfully restructured and hence continued to play an important role in the Malaysian economy.Yet it can be also argued that the government achieved success because it already had before the crisis better governance and the enterprises were better managed than compared to some of the badly affected neighbours. The crux of the problem, imprudent foreign borrowing, was limited (not true of domestic borrowing which was very high) because of restrictions put in place before the crisis. ( Case 2003 )

\section{Role of the Multinationals in the recovery}

A major reason for the recovery however has to do with the structure of the Malaysian economy where there is a big well managed area consisting of the export of manufactures. The fact that the manufacturing sector occupies such a big size of the Malaysian economy and that the multinationals (MNEs), play such a big part in the export of manufactures have cushioned the extent of the economic contraction experienced in 1998 and helped the recovery subsequently. The size and role of the manufacturing sector can be gleaned from the figures for 1997.In that year,the manufacturing sector accounted for 36 percent of total GDP in the country, and the export of manufactures amounted to 81 percent of total exports of Malaysia. Regarding the role of the MNEs, this can be seen first from the fact that electronic exports constituted the single largest manufacturing sub-sector that is contributing to total exports and this electronics exports in 1997 amounted to RM80.8 billion or $37 \%$ of total exports in the country.! And this electronic sector is overewhelmingly dominated by foreign investors as $100 \%$ foreign equity participation has been allowed in the Free Trade Zones and for export activities. One scholar,Athukorala $(2003,20)$ found that multinationals accounted for $93 \%$ and $91 \%$, respectively of the value added in the consumer electronics, and of the semiconductor and electronics industries in Malaysia. This sector was also found to be among the manufacturing sub sector with the lowest measured contraction in output and employment during the crisis. He further added that other industries with higher MNE presence were also found to have 
a smaller contraction of output and employment. This finding is important in view of the fact that MNEs have been found to account for 73\% of total exports in 1995 (Tham 2004, 220).

Given the structure of the economy and the fact that the crisis occurred during a downturn period and overcapacity in the semiconductor industry cycle that stretched from 1996-1998 (Matthews 2005, 25), one would expect exports to fall from 1997 to 1998. Instead, it is interesting to note that although the US dollar value of exports declined from USD78.7 billion in 1997 to USD73.3 billion in 1998, export volumes actually expanded by 1.1\% in 1998 (WTO 2001, 3). Electronics exports grew to 41\% of total exports in the country in the same year. While Malaysia's exports to ASEAN declined by $19.2 \%$ in 1998 as their economies contracted, those to the European Union and the United States rose by 4.2\% and 8.3\%. respectively, compared to 1997. Hence, the resilience of Malaysia's export volumes, in the face of a financial and economic crisis that was further exacerbated by the downturn in the global electronics cycle, can be attributed to the sustained trading activites of the MNEs with their parent companies in the USA or Europe throughout the crisis.

\section{Development of the Malaysian economy after the crisis}

Subsequently, the economy rebounded sharply in 1999 with a growth of $6.2 \%$ due to several factors. First, the upturn of the global electronics cycle between 1999-2000 (Matthews 2005, 25) enabled electronics exports to recover, thereby leading to Vshaped recovery pattern experienced in 1999 and sustained till 2000. The share of electronics exports in total exports grew further to $45 \%$ in 1999 while total exports grew from RM281.7 billion in 1998 to RM319.6 billion in 1999. Imports also grew given the intra-industry and intra-firm nature of trade in the electronics sector, albeit less than the growth in exports, resulting in an expansion of the trade surplus from RM69.2 billion to RM86.0 billion (Table 1). Inflows of FDI also increased from RM8.4 billion to RM9.3 billion as the region recovered from the crisis and with the partial restoration of investor confidence. Per capita income grew from RM8.2 billion in 1998 to RM8.5 billion in 1999, close to the pre-crisis level of RM8.7 billion in 1996. In 2000, per capita income increased to RM9 billion, thereby exceeding the pre-crisis level in 1996.

Although the government abolished the $10 \%$ tax on portfolio investments taken out of the country(part of the selective capital controls) on May 2001, this did not seem to have any positive effect on the economy. Instead, Malaysia's continued dependence on the exports of electronics products implied that the economic growth in the country continued to be vulnerable to global fluctuations in the demand for these products. The recession in the USA reduced demand for electronics, together with global over investment in new capacity in this sector resulted in another downturn in the global electronics cycle in 2001-2002. The adverse external circumstances in turn affected Malaysia's exports as it shrank from RM374 billion to RM334 billion from 2000 to 2001 while growth contracted from $8.9 \%$ to $0.3 \%$ over the same period. At the same time, the drop in global FDI flows in 2001 as well as increasing competitiveness for FDI from China, India and Vietnam, resulted in a severe drop in FDI inflows into Malaysia. Internally, the deteriorating comparative advantage in the country for the production of lower value-added, labor-intensive products served to reinforce the negative impact of the increasing competitiveness for 
FDI. Thus, in 2001, inflows of FDI into Malaysia was merely RM1.1 billion, almost a tenth of the FDI inflows in 1995.

Economic growth recovered in 2003 and 2004 to 5.4\%and 7.1\%, respectively but the global cyclical slowdown and rise in oil prices in 2005 together with the emergence of exogenous shocks such as the tsunami and the avian flu slowed the growth in 2005 to 5.2\%. Although FDI flows have recovered and increased to RM9.7 billion in 2004, this is still short of the RM10.5 billion that was attained in 1995, reflecting not only the loss in the relative attractiveness of Malaysia as a host economy for the production of lower value-added products but also the difficulties encountered in shifting towards the production of higher value-added products as aspired by the country. The sizeable trade balances that have been accumulated from 2002 onwards may be indicative of an undervalued Ringgit as the peg was maintained right up to July 2005 before it was dismantled and replaced by a managed float system based on a basket of currencies. This marked the end of almost all the capital controls that had been established in September 1998.

\section{2)The Impact on the Malaysian Chinese Business Firms 1}

Malaysian Chinese business firms were not as badly affected as many of the large non- Chinese firms in Malaysia. They also fared much better as compared to their counterparts in Thailand and Indonesia. Many of the big Malaysian Chinese firms remained intact. What were the reasons in Malaysia for some surviving and some going under?

We have first to distinguish between two levels of Malaysian Chinese business as it is not homogeneous. The first level consists of the big business groupings, and the second, the small and medium enterprises (SMEs). It is not the intent here to go into the precise delineation of all the two levels as the definition of a group like the SMEs keeps changing. Suffice it here to say that as far as the Chinese SMEs that are defined by Chinese related associations are concerned, these Chinese SMEs, in general, have survived reasonably well. Many were spared the worst of the crisis because they were less exposed to over borrowing. In particular, certain SMEs had benefited from the effective devaluation of the Malaysian Ringgit which aided the competitiveness of Malaysian products in the international arena. A sizable percentage of the products of Malaysian SMEs were for the export market.

Nevertheless, the lift from the currency devaluation proved to be only temporary. The other side of the coin of devaluation was that the price of raw materials and component parts for some SMEs had gone higher as to increase the cost of production. More significant was the fact that the SMEs had to cope with the removal of import duties as Malaysia prepared for the requirements of the WTO and the ASEAN Free Trade Area (now reconstituted as the ASEAN Economic Community). And even more important, the import of very competitive mainland Chinese products, also had a tremendous impact. Thus Malaysian Chinese SMEs involved in the manufacture of shoes, furniture and textiles are badly hit by these developments. Some of these SMEs have now turned from manufacturing to trade. Many are now for example importing textiles, (which they once manufactured!) from China to Malaysia.(Lee.2006,177 ) 
It is however in the big Chinese business groups that we are focused here. This group for our purpose consists of those Chinese controlled firms in the Malaysian stock exchange and those others that have been identified as such by international and local business journals. In general, those, which responded to the crisis fell into two groups; those that survived relatively unscathed and those that went under. The reasons for the survival of the first have to do with the sector they are in and their business strategies, and also their sound management and the relative absence of imprudent borrowing. We can have some idea of this by examining a list of the top 20 businessmen in Malaysia as published in February 2001 by Malaysian Business, the leading Malaysian business magazine published in Kuala Lumpur. The list is particularly appropriate as it comes out just shortly after the crisis and hence reveals its immediate impact. The list gives the names, the estimated value of the businessmen and the sectors they are in. What is striking is that of the 20 businessmen listed, the vast majority, 16, are Chinese.This suggests Malaysian Chinese business was not devastated and still remained in a very influential position in the Malaysian economy.What were the reasons for their resilience? The list below (Table 2) of the top 15 Malaysian Chinese businessmen can give us some clue.

\section{Table 2}

Individual

1. Robert Kuok

2.Lim Goh Tong

3.Quek Leng Chan

4.Yeoh Tiong Lay $\quad 5.5$ billion

5.Tiong Hiew King 3 billion

6.The Hong Piow

7.Loh Cheng Yean

8. Lee Oi Hian

9.Lee Shin Cheng
9.6 billion

9.2 billion

2.8 billion

1.4 billion

Estimated Value(RM)

15 billion

3 billion

1.2 billion

1.19 billion
Sector

media, plantations, shipping; 13.5 billion in overseas assets

casino, plantations, power, property oil and gas

property, banking, manufacturing; investments in Hong Kong and New Zealand

construction, power, utilities

timber, banking, insurance, media; investments in Hong Kong, US, Canada, Solomon, Papua New Guinea

banking and financial services; Hong Kong and Bermuda investments

motor distribution, plantations, properties, manufacturing

plantations and plantation related manufacturing

plantations, properties and manufacturing 


$\begin{array}{lll}\begin{array}{l}\text { 10.Tan Kim Hor } \\ \text { 890 million }\end{array} & \begin{array}{c}\text { motor distribution, trading, and } \\ \text { manufacturing }\end{array} \\ \begin{array}{l}\text { 11.Khoo Kay Peng } \\ \text { education, }\end{array} & \text { insurance, hotels, retailing, } \\ \text { and } & \text { investments in Hong Kong, U.S. }\end{array}$

Australia

12.Low Yow Chuan 596 million properties and hotels

13. Yaw Teck Seng 542 million property development and plantations

\section{Lau Hui Kang 500 million}

15. Tan Chin Nam
Timber, plantations, aquaculture, tourism

property and overseas investment.

The one thing we can draw from this list are the large number of them that are involved in sectors that are not so directly hit by the crisis, such as in manufacturing, retailing, motor distribution, education and plantations. Those involved in the plantations, in particular in the growing of palm oil, are quite well placed. Their palm oil is exported. Their revenue is derived from dollars while their payment for wages is in Ringgit! To be sure, quite a few are involved in those sectors that are directly hit by the crisis such as in banking and property development. But from what is known of those involved in these two sectors, they have overcome the impact through sound management. Public Bank and Hong Leong Bank controlled by Teh Hong Piow and Quek Leng Chan respectively have the reputation of good management. Their banks have among the least number of non performing loans. Similarly, the property developers, such as Low Yow Chuan and Tan Chin Nam, are involved in property development long before the crisis. Also, property development constitute their core business. They are likely to have solid property projects that have made substantial profits already or that are not so susceptible to loan exigencies. They are not like so many of the other property developers hit by the crisis who were mainly speculators who borrowed money when it was freely available to try their luck on property development. A final notable feature is the number of them who have diversified outside of Malaysia. Robert Kuok, the richest of them all, be it noted, has 13.5 billion Ringgitout of a total of 15 billion Ringgit outside Malaysia. An example of his involvement overseas is his chain of Shangri-La hotels, the brand for which he is most famously associated with. As of March 2005, there are fifty-five Shangri-La hotels worldwide, out of which only eight of these are in Malaysia! Geographical diversification of business does not necessarily mean that such businesses can be immune from the crisis. If they have diversified their business and assets to stricken countries like Indonesia, Thailand and Hong Kong,(as happened in the case of T.K. Lim below) they will not be much better of. However, by and large, most of these 
Malaysian Chinese businessmen will have diversified into countries in the West, including Australia, and China where the crisis did not hit.

Those Chinese companies that went under did so primarily because of heavy debt or speculation and over expansion. Many of such companies were placed under the Danaharta special administration. As of December 2000, 32 out of 76 companies placed under Danaharta special administration were identifiably Chinese owned. The typical modus operandi of many of the owners of these companies in the period before the crisis were to take huge loans, when they were easily available, to acquire properties and listed companies. Then they used the acquired shares to make further acquisitions of targeted companies with the aim of driving up share prices before disposing them at a huge profit. Speculation, rather than sound management of the acquired companies, was their motive, and hence it was not surprising that once the crisis hit, causing a precipitate drop in share prices and a currency devaluation, many of these companies would go under. Two examples of Malaysian Chinese businessmen who came to grief as a result of the crisis were Joseph Chong Chek Ah of Wing Tiek Holdings and Westmont Industries. Chong over expanded by acquiring Sabah Shipyard and attempted to acquire the National Steel Corporation of the Philippines. Already financially strained before the crisis, the crisis greatly aggravated his debt problems and his companies went under Another example of a businessmen whose reach exceeded his grasp is $\mathrm{T}$. K. Lim who, through his property listed company, Multi-Purpose Holdings, went on a huge expansion, incurring debts of as much as RM 2.2 billion. Needless to say his companies went under as a result of the crisis.

It has to be said that there are companies which lay in between these two groups, in particular those which have some of the attributes of the first group, such as concentration on core business and reasonably sound management but which, because of their indebtedness, went through a difficult period and had to undergo a restructuring process. Two of the more prominent examples are the Sunway group under Jeffrey Cheah and the Lion Group under William Cheng. The former, primarily involved in the property business (housing development, hotels and resorts) went through a difficult stretch as a result of over borrowing but because of its extensive assets and its track record, was able to pull through, though he had to sell some of its assets in the process. Evidence of this success can be found in the publication by the leading English newspaper in Malaysia, the Star(Star2007) in 10 February 2007 of a list of the top 30 Malaysian businessmen. Jeffrey Cheah occupied the $25^{\text {th }}$ place with assets valued at 515 million Ringgit for 2006.The latter, William Cheng, had businesses that were much more diversified than Jeffrey Cheah (retail, steel making, heavy business involvement in China) but his group, the Lion Group, became heavily indebted to the tune of about 10 billion Ringgit out of which half were secured in US dollars. Many of the companies in his group had to be restructured through the CDRC. The restructuring however was successful and he is now the $13^{\text {th }}$ richest Malaysian businessman, according to the Star list, with assets estimated at 961 million Ringgit for 2006. He is also now reputed to be one of the biggest Malaysian investors in China.

\section{3)Impact on the political system}


Malaysia did not experience the far reaching political change as occurred in Indonesia where the crisis brought about the overthrow of the military strong man, Suharto, and ushered in democracy and decentralization in the political system. There was no change in the constitutional structure, and the coalition, which ruled the country since independence in 1957, of the various mostly racially, based parties under the dominance of the Malay party, UMNO, remained intact after the crisis. This coalition still governs up to now. But this does not mean that the political system, in particular the dominant party, UMNO, did not undergo turbulence. What in fact happened was that the incipient split between the deputy president of UMNO, Anwar Ibrahim, and the president, Mahathir Mohamad, came into the open after the crisis began. This split, which many observers believed, began in 1993 when Anwar overwhelmingly defeated Ghafar Baba, the then deputy president of UMNO, for the deputy presidency of the party, greatly unnerved Mahathir who was then the president. Thus this Anwar, whom Mahathir himself brought into UMNO, had begun to control the party and possibly isolate Mahathir within it. It was not something that Mahathir could for long tolerate. He began to see Anwar as a threat. And it became an open secret that both were increasingly not able to get along politically. And since then Anwar became increasingly identified with a reformist political philosophy,(an identification which came out openly after the formal split) a philosophy that is associated with a nonauthoritarian Western style democracy where civil society can flourish as opposed to the more authoritarian style democracy ( a 'Malaysian democracy' or a limited democracy), often justified by what maybe called the 'Asian values,' 2 of Mahathir..(Khoo.2005,23)

Both held their split within check until the Asian crisis erupted when Anwar made, or was seen to make, moves that were interpreted by Mahathir and his supporters to be a challenge to Mahathir's authority. Two such moves were significant. One was the use by Anwar's supporters after the crisis struck of language that suggested that Mahathir's time was up, language that were echoes of those used by the anti-Suharto forces in Indonesia. Thus, the Anwar people began for example to use the acronym KKN (korrupsi, kronisma and nepotisma,(( corruption, cronyism and nepotism in Indonesian))) which had a powerful effect on the overthrow of Suharto, and which could similarly be applicable to the Mahathir government in Malaysia. The second was the championing by Anwar of the acceptance of IMF loans and the resulting conditionalities. Such acceptance could have the effect of dismantling the monopolies so important to the political power of Mahathir. Mahathir hit back. He expelled Anwar, when Anwar refused his demand that he resigned, from the party, and had him tried and subsequently convicted of the charges of sodomy and corruption.(The charge of sodomy has subsequently been overthrown.) Anwar retaliated by taking to the streets, before his incarceration, with his supporters with the message of reformasi or reformation. Anwar won much sympathy in Western circles with his message of reform. A particularly noteworthy example of this sympathy was the message delivered by the American Vice-President, Al Gore, who represented President Clinton in the APEC summit in 1998 in Kuala Lumpur. His message contained an encouraging reference to the forces of reformation in the area, a message widely interpreted in Malaysia as support for Anwar.

The Anwar expulsion shook the party and left a big gap in the succession, which was only filled much later with Mahathir appointing the present prime minister, Abdullah Badawi, as the deputy president. The Anwar factor had the initial effect of 
weakening Mahathir's authority within the party of UMNO and made a big dent in the Malay support for UMNO in the 1999 Malaysian general elections. The National Front, the ruling coalition had control of all the state legislative assemblies in the 1995 elections.(state elections and general elections are nearly always conducted at the same time.) They however lost two Malay states, Kelantan and Trengganu to the opposition. And in the general elections proper, the Front saw the percentage of their popular votes dropped from a high of 65.2 in 1995 to 56.5 in 1999.The percentage drop in the seats were from 84 percent in1995 to 77 percent.(Khoo.2005.42,44) ) This dent in the strength of Mahathir and the National Front was widely attributed to the Anwar factor. But the National Front subsequently recovered from this Anwar factor when Mahathir handed over the premiership to Badawi in late 2003. In the subsequent general election, which followed in 2004, Badawi led to the Front to an overwhelming victory. It won back the state of Trengganu and narrowly missed recapturing the state of Kelantan. It also obtained a higher percentage of the popular votes and seats than it did in 1999.

It would seem that the Anwar factor and his message of reformation made an impact on Malaysian politics only for a short while after the crisis. Yet it cannot be said that the ideology, if it can be called that, of 'Asian values', with Mahathir finally overcoming Anwar, has triumphed. For while Mahathir, together with Lee Kuan Yew, the former prime minister of Singapore, had been associated with the championship of 'Asian values',(Lee would however insist that what he meant are Confucian values) these 'Asian values" had credibility only in so far as those championing it would find their paternal style of government consonant with the values of their society. And in particular, such governance by these paternal leaders was deemed to be responsible for the impressive economic development of their societies. The early 1990s apparently showed that such 'Asian values' had some currency.The Malaysian and Singaporean economies were growing at a fast pace. Both Mahathir and Lee Kuan Yew ( retired as Prime Minister in 1990 but became Senior Minister in the government) enjoyed popularity among their people and were able to counter the argument that a Western style democracy was needed for Asian societies to develop.

The crisis however laid low the economy of Malaysia and the Anwar challenge showed that there was another form of governance that maybe more in consonance with the world wide trend. 'Asian values' would seem to be discredited. But because of Anwar's ouster by Mahathir, Anwar's reformation did not succeed. The judgments of two writers, Thornton and Song ( Thornton 2006)can be applied to the Malaysian case. Both 'Asian values' and neo-liberal capitalism, they argued, lost credibility in the post-miracle years. They however added an optimistic note. The silver lining in the crash, they continued, is the enormous emancipatory potential of 'unguided' political reforms. This maybe the case in Malaysia where reform remains a potentiality rather than an actual reality. There is increasing talk after the crisis of reform ( of going against corruption, of a more open government and so on) but it is not making much headway because of the entrenched system The judgment of one Malaysian scholar, Francis Loh, aptly sums up the situation after the crisis. 'Thanks to the end of Mahathir's long 22 years in power', Loh writes, 'and the Abdullah takeover, there had occurred some initiatives towards political reform, at least in terms of rhetoric... but these reforms have not been allowed to develop further due to severe structural constraints inherent to the centralized political system first put into 
place by Mahathir, and not removed in any dramatic fashion by Abdullah (Badawi)'. (Loh.2006)

\section{Impact on the 'Look East' policy}

The argument put forward here is that the Look East Policy (LEP) was essentially a rationale or justification for government intervention in the economy that began with the New Economic Policy(NEP) in 1970. While the NEP operated on the somewhat contradictory (as seen by lassaiz faire theorists) basis of growth with redistribution, the adoption of the LEP brought a new dimension to state intervention in the economy. For, as was believed of the way the Japanese model operated in the early 1980s, around the time of the Look East policy, a particular form of state intervention in the economy can not only bring about great economic growth but also social stability. Thus the adoption of the Japanese model enabled the defenders of the NEP to argue that there need be no contradiction between growth and redistribution (understood as Bumiputra participation in the economy) but both can go together. The crisis proved this not to be true. But as stated previously, because the extent of the damage wrought by the crisis was not as great as compared to some of its neighbors and because of the successful attempt of the government to rescue many of these groups, the crisis did not fundamentally alter the structure of state involvement in the economy that had its origins with the NEP. What the crisis did was to erode the rationale that this structure could bring about great economic growth, the kind that was achieved by Japan in the 1970s and the 1980s. The defense of this structure has thus fallen back on the old rationale of redistribution and a new tentative (defensive?) rationale maybe developing that state guidance was needed to enable business to meet international competition brought about by globalization

\section{Background to LEP}

The NEP, which was introduced in 1970, had as a primary objective that of enabling bumiputras to participate meaningfully in the Malaysian economy, But this had to be accomplished in the context of economic growth. While by late 1981, the time of Mahathir's ascendancy to the premiership, the Malaysian government had achieved this goal to some extent, there was always the belief held in some quarters that such a policy is somewhat contradictory (achieving growth with redistribution?) or that without the redistributory policy, economic growth in Malaysia would have been far greater. Such doubts were then greatly reinforced around that time by the increasing predominance in the global arena of the lassaiz faire philosophy of Thatcher-Reagan. Thatcher had become prime minister in 1979 and Reagan was elected to the presidency in 1980. Both waged a vigorous campaign against state involvement in the economy, their buzz words were 'the magic of the marketplace', liberalization, deregulation and privatization. Mahathir could not have been unaffected by this. But having been elected as the head of UMNO, a Malay party with a deep belief in state intervention in the economy to favor the bumiputras, there was little chance he would accept the Thatcher-Reagan lassaiz faire philosophy for Malaysia.

At the same time, Mahathir was looking for a new stage for the NEP. He saw the inefficiency in the first decade of the NEP (the 1970s) of many of the state controlled business enterprises for the aid of bumiputras in business, and believed that the creation of a Bumiputra Commercial and Industrial Community (BCIC) would be a better way of implementing the NEP (Khoo.2005.26 ). This however did not mean 
the adoption of the lassaiz faire philosophy. Rather because the BCIC had to be created almost from scratch, state involvement in the economy remained essential.

How then to justify this continued state intervention in the economy to aid the bumiputras beyond the rationale that social stability depended on the equitable distribution of wealth. The answer came in the Japanese model. Japan by 1981 had not only rebuilt its war torn economy but had built an economy that was not only the second largest in the world but was dazzling this world with the its conquest of global markets and its introduction of technological and managerial innovations. It could not have escaped Mahathir's notice that Japan was doing all these while maintaining social stability and national identity. Japan thus had developed a political economic system that combined economic growth and development with a form of redistribution. He could also use the Japanese model to rebut the Thatcher-Reagan philosophy that only the lasseiz faire approach can bring about high economic growth.

The essence of the emulation of the Japanese model was Malaysia Incorporated, after the fashion of Japan Incorporated, which had its basis a cooperative relationship between government and business, a relationship mainly aimed at the development of a Bumiputra Commercial and Industrial Community.. There were however criticisms of this policy. Some believe this relationship distorted economic development and was suggestive of undue favoritism to certain businessmen. Mahathir was able to ride out such criticisms and could argue his policy worked because of the high growth rate of the Malaysian economy up to the time of the crisis. He(and other Malaysians) could not have been unmindful of the fact that the World Bank praised Malaysia when it included Malaysia in 1993 as one of the eight high performing Asian economies alongside with the likes of Hong Kong, Singapore and South Korea.

The Asian crisis brought Malaysia Incorporated crashing down. Quite apart from the fact that it brought about a marked descent in the growth rate, it also exposed the lack of sound management of some of these favored enterprises. Many of these enterprises had to be rescued by government. This , according to one scholar,Jomo, created public outrage when the politically connected or influential sought aid from 'government controlled public (EPF, Permodalan Nasional Berhad (PNB) and Khazanah) funds as well as diverted private resources.'( Jomo.1998)Increasingly, many in Malaysia came to the conclusion that the crisis had dealt a severe blow to the credibility of the Japanese model in Malaysia in that it had shown that excessive state intervention did not work.

But because Malaysia did not accept IMF loans, the fundamental structure of the relationship between government and bumiputra business remained. The rationale that Malaysia Incorporated, as in Japan Incorporated, could produce the economic miracle, had been destroyed. Faced with this new reality, Mahathir then argued that the LEP was not entirely a failure as it had aided race relations in Malaysia.( New Straits Times 2000). By that is meant that LEP had aided the redistribution of wealth to the Bumiputras.Thus the justification of the continuing tight relationship between politics and business which survived the crisis will fall back increasingly on the NEP. 'In fact' as Pepinsky writes, 'the regime’s(Malaysian government) continued emphasis on the NEP-despite the fact that it officially expired in 1990- provides ideological cover for much of the regime's continuing involvement in the economy'. (Pepinsky 2007 ) 
There will of course be some changes from the Mahathir government under Mahathir's successor, Badawi.The Badawi government appears a bit more responsive to efficiency criteria and market signals. Some of the Badawi people now put in charge of government linked organizations talk of introducing performance criteria ('key performance indicators' is their buzzword) in order to tighten things up. And in order to staunch the losses suffered by Proton, the national car maker, the Badawi people are willing to consider selling a substantial, if not a controlling, stake to a top foreign car manufacturer. But such changes will be minor and will not affect fundamentally the relationship between government and bumiputra business.

There is however a possibility a new rationale may develop for state intervention, that it is needed to prod private business to take the necessary steps to meet international competition or the challenge of globalization. Apart from exhortations by government to business to be more competitive, there has been pressure on key sectors, such as banking, to consolidate to meet the challenge of financial liberalization. Thus there was the attempt by the former finance minister, Dim Zainuddin, to force the banking sector to group under six anchor banks. That was conceived before the Asian financial crisis but greatly took on momentum after the crisis. Daim's plan was met with strong criticism as not being well conceived and unfair to Chinese banks (only one Chinese controlled bank 'Public Bank' was among the six).(Gomez.2001) The number of anchor banks was subsequently increased to ten with another Chinese controlled bank, Hong Leong Bank included.To date the consolidation is still to be achieved. Other plans are also in the air for the consolidation of the plantation industry.

\section{Conclusion}

Malaysia did experience economic and political turmoil as a result of the Asian financial crisis, though not as badly as some of its neighbours. Its economy contracted but recovered soon after in part because of the steps taken by the government to stabilize the economy, and in major part because of the large role the multinationals, largely unaffected by the crisis, play in the economy, especially in the export of electronics. The export of electronics cushioned the contraction and aided in the recovery though, given increasing competition for foreign investment by a rising power like China, it remains to be seen for how long electronics can be the driving force of the export of manufactures by Malaysia. The crisis also had an impact on a very big portion of Malaysian business, that of Malaysian Chinese business. But it was not devastating. Many big Malaysian Chinese businessmen survived because they were not caught up in imprudent overborrowing from foreign sources and had generally well managed enterprises.

On a political level, the crisis did not affect the constitutional structure. The role of the bureaucracy also did not change fundamentally. However the crisis brought into the open the split between Mahathir and Anwar in the dominant political party, UMNO.Though Anwar was ousted from the party, neither the 'Asian values' associated with Mahathir nor the reforms associated with Anwar triumphed. Reform remains a potentiality rather than an actuality.Finally, the crisis eroded the rationale that the Look East Policy which justified a particular form of relationship between government and business, can bring about both impressive economic growth and social stability. 


\section{Notes}

1. Much of this section is taken from "Malaysian Chinese Business:Who Survived the Crisis?” by Lee Kam Hing and Lee Poh Ping in the Kyoto Review of Southeast Asian Studies, Kyoto University(online journal), October 2003. It has however been updated.

2. Anwar Ibrahim recently reiterated his stand that in the fight against Mahathir, he was opposed to Mahathir's 'Asian values'. See his interview with Al Jazeera English on 13 January, 2006 under the programme '101 East'.

\section{References}

Athukorala, P. 2002. Malaysian Trade Policy and the 2001 WTO Trade Policy Review. The World Economy 25 (9), 1297-1317.

Athukorala, P. 2003. FDI in Crisis and Recovery: Lessons from the 1997-98 Crisis. in Hill, H. and Lindblad, T. (eds.), Australian Economic History Review (Special Issue, Financial Institutions and Economic Crisis in Asia).

http://rspas.anu.edu.au/economics/publish/papers/wp2003/wp_econ_2003_04pdf. Accessed 4 February 2007.

Chin Kok Fay.2004. Malaysis’s Post-Crisis Bank Restructuring. In After the Storm, Crisis, Recovery and Sustaining Development in Four Asian Economies edited by K.S.Jomo. Singapore University Press .

Case,William 2003.Malaysia:New Reforms, Old Continuities,Tense Ambiguities. Working Paper Series No.51,September 2003.SEARC, City University of Hong Kong

http://www.cityu.edu.hk/searc

Accessed 11 October 2006

Gomez,T.2001.Why Mahathir axed Diam. Far Eastern Economic Review 5 July 2001. Reprinted by Aliran Monthly 2006:1

http://www/aliran.com/content/view/40/10/

Accessed 15 February 2007

Khoo Boo Teik 2005.. Limits to Democracy, Political Economy, Ideology and Ruling Coalition. Elections and Democracy in Malaysia edited by Mavis Puthucheary and Norani Othman. Universiti Kebangsaan Malaysia, Bangi, Malaysia

Jomo K.S.1998. Malaysia:From Miracle To Debacle. Tigers in Trouble, Financial Governance,Liberalisation and Crises in East Asia edited by Jomo K.S. Zed Books Ltd. London

Jomo K.S. 2004.Were Malaysia’s Capital Controls Effective? In After the Storm, Crisis, Recovery and Sustaining Development in Four Asian Economies edited by K. S.Jomo, Singapore University Press. 
Lee Poh Ping and Lee Kam Hing.2006.China’s Economic Rise and Its Impact on Malaysian Chinese Business. Southeast Asia's Chinese Businesses in an Era of Globalisation, Coping with the Rise of China. Edited by Leo Suryadinata.ISEAS, Singapore.

Loh, Francis.2006 A season of odd and silly events.Aliran Monthly 2006:9 http://www.aliran.com/content/view/183/10/

Accessed 2 February 2007

Matthews,J.A.2005. Strategy and the Crystal Cycle. Califonia Management Review, Vol.47,No.2, Winter,6-31

New Straits Times.2000. The New Straits Times (Kuala Lumpur) 25 July,2000.

Pepinsky,Thomas.2007.Institutiions,Economic Recovery, and Macroeconomic Vulnerability in Indonesia and Malaysia. Revised paper presented to a conference on the Asian Financial Crisis organized by Institute of East Asian Studies, UC (Berkeley) in Fall 2006.

Star,The,2007. Bizweek:Malaysia’s Billionaires Club. The Star(Malaysia) 10 February 2007

Tham Siew Yean 2004. Malaysia. Chapter 6 in Hill, H. and Brooks, D.H. (eds.), Managing FDI in a Globalizing Economy: Asian Experiences. Houndmills: PalgraveMacmillan.

Thornton, William H. and Song Kok Han Thornton..Mapping the Invisible Asia:'Sexism' and the Politics of Transnational Capitalism. Znet

http://wwww.Zmag.org/content/showarticle.cfm?Section1D=44\&Item1D=1176

Accessed 12,October,2006

Tourres,Marie-Aimee.2003. The Tragedy That Didn't Happen. Institute of Strategic and International Studies(ISIS)Malaysia.

WTO 2001. Trade Policy Review: Malaysia. WT/TPR/S/92. 